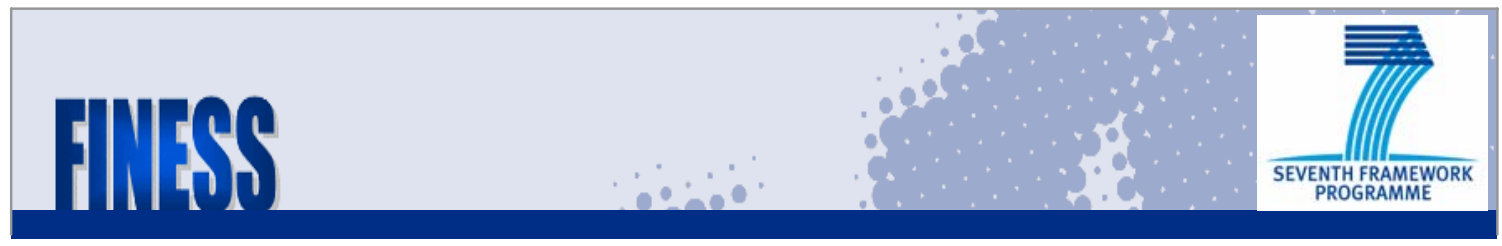

Project funded under the Socio-economic Sciences and Humanities

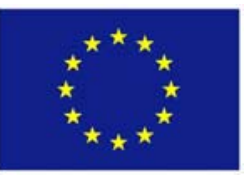

Working Paper D.2.1

European Commission

\title{
Bank market structure and firm capital structure in Europe
}

Lieven Baert and Rudi Vander Vennet

July 2008 


\title{
Bank Market Structure and Firm Capital Structure in Europe
}

\author{
Lieven Baert* \\ Ghent University \\ Rudi Vander Vennet \\ Ghent University
}

\begin{abstract}
We explore the impact of concentration in the banking markets on the capital structure of publicly quoted non-financial firms in the EU15 over the period 19972005, an era marked by intensive merger activity in the banking sector. Our main finding is a negative and significant relationship between the degree of concentration of European bank markets and the market leverage of firms, indicating the persistence of credit constraints. This finding is robust when we use behavioral measures of bank conduct. This support for the market power hypothesis indicates that further measures are needed to make bank lending more competitive.
\end{abstract}

Key words: Bank concentration, Capital structure

JEL classification: G21, G32

* Corresponding author

Email address: lieven. baert@ugent. be (Lieven Baert). 


\section{Introduction}

The positive role of the banking sector in enhancing economic growth through a more efficient resource allocation has been widely documented (Levine and Zervos (1998)). Since banks are important suppliers of funds to firms, the structure of bank markets as well as the effects of market structure changes on the lending behavior of banks may have an impact on the access of firms to bank finance. It is, however, unclear how bank market structure changes may affect the access of non-financial firms to bank lending (Black and Strahan (2002)). More concentrated banking markets have been found to lead to lower growth, except for industries that depend heavily on external finance (Cetorelli and Gambera (2001)). In this paper we examine empirically whether changes in the structure of European bank markets affect the access of non-financial firms to bank finance. More specifically, we investigate the relationship between the degree of concentration of European bank markets and the capital structure of non-financial firms.

Banks have been and remain the dominant source of debt financing for European companies. During the last decade, the European banking sector has been characterized by a wave of mergers and acquisitions, predominantly

in the form of domestic consolidation (ECB (2006)). The result has been a substantial increase in the measured level of bank market concentration in most countries. Similarly, European bond and stock markets have witnessed a pronounced development and integration since the introduction of the Euro (Rajan and Zingales (2003)). These developments in the bank and financial markets make the period under consideration, 1997-2005, and the geographical scope (EU15) particularly interesting to investigate the impact of the evolving 
market structure of financial intermediaries on external financing decisions by non-financial firms.

By investigating the relationship between bank market concentration and firm leverage this paper relates to the empirical corporate finance literature (Rajan and Zingales (1995), Fama and French (2002), Flannery and Rangan (2006)). The paper contributes to two strands of this empirical literature. The first is the recent literature which examines how the supply of external finance affects the corporate finance behavior of companies (Faulkender and Petersen (2006), Leary (2005), Lemmon and Roberts (2007)). Bank loans play a less important role in the financing of large U.S. companies (Danthine et al. (2002), Saidenberg and Strahan (1999)), therefore these papers do not investigate bank loan financing ${ }^{1}$. We argue that the EU countries are a well suited geographical area to examine the role of bank loan supply because domestic mergers and acquisitions have fundamentally altered the market structure of banking under the period of investigation. This allows us to exploit both time and cross-country variation to examine the role of bank loan financing on the capital structure of firms. Moreover, since the introduction of the Euro, bonds and equity have become more important alternatives for external finance next to bank loans in the EU. Therefore, we can account for the increasing competition between banks and financial markets.

A second line of corporate finance literature investigates the role of institutions on corporate financing choices (Demirgüç-kunt and Maksimovic (1999), Giannetti (2003), Fan et al. (2006)). We contribute to this evidence by instrumenting the observed bank market structures using measures of competition

$\overline{1}$ An exception is Leary (2005) who uses two natural experiments from the 1960s. 
policy from Carletti et al. (2008). Our final contribution relates to the literature which examines the role of bank market structure on the external finance behavior of companies (Petersen and Rajan (1995), Zarutski (2006)). First, we examine listed companies instead of small and medium-sized companies. Second, we use not only the usual concentration measures (HHI, CR5) but also behavioral measures (Lerner index and Boone indicator).

The sample period covers sub-periods characterized by different business cycle conditions, so that our results are not driven by specific macroeconomic conditions. Methodologically, as in Faulkender and Petersen (2006), we attempt to integrate demand and supply factors that may affect leverage decisions by non-financial corporations. Furthermore, we exploit the panel structure of the data by using a sample of individual firms across different years, allowing us to use firm fixed effects (Lemmon, Roberts and Zender (2006)).

Our main finding is a negative and significant relationship between the degree of competition in the European bank markets and the market leverage of firms, implying that increased concentration of bank markets imposes an external debt finance constraint on non-financial firms. These findings are robust when we use behavioral measures of bank competition, instead of the traditional market structure indicators. Our findings strengthen the case for further regulatory action aimed at stimulating competition in European banking markets.

In the next section we state the main hypotheses: the information-based hypothesis and the market power hypothesis. The empirical strategy which integrates the demand and supply factors for corporate leverage is outlined in Section 3. We then present our data on listed non-financial firms, different 
bank market structure variables and measures of alternative external finance (section 4). In section 5 we examine the determinants of leverage and the impact of our measures of market structure. The bank market structure variables are instrumented and we check the robustness of the results. We conclude in Section 6 and present broader implications of our findings.

\section{Determinants of corporate leverage: supply and demand factors}

This paper examines the effect of bank market concentration on the availability of bank loans to non-financial firms. The literature has identified two alternative hypotheses, the market power hypothesis and the information-based hypothesis. Banks have an informational advantage over public lenders. Higher bank market concentration may make banks more efficient and strengthen this information advantage, thereby inducing banks to invest more in relationships. This should mitigate the asymmetric information problem which is the main cause for credit rationing (Stiglitz and Weiss (1981)) and therefore lead to more lending and hence, to higher observed levels of corporate leverage. We call this the information-based hypothesis. The alternative hypothesis is the market power explanation. Several theories predict a negative effect of bank consolidation on the availability of loans. A non-financial company which is confronted with a concentrated banking market may face less attractive loan conditions when banks effectively use their market power. As a result firms will decrease their use of bank debt and exhibit lower leverage, assuming the absence of alternatives for external debt finance. We call this the market power hypothesis. Previous empirical studies have reported mixed results. On the one hand Petersen and Rajan (1994) and Zarutskie (2006) find sup- 
port for the information-based hypothesis. Petersen and Rajan (1994) find that a change in the bank market Hirschmann-Herfindahl Index (HHI) of 0.1 increases the ratio Total Debt/Assets of a typical firm by 0.36 percent. Zarutskie's (2006) main finding is that the firm Outside Debt/ Assets increases by between 0.19 and 0.77 percent following an increase in HHI of 0.1 . On the other hand Carbó-Valverde et al. (2006) examine firm borrowing constraints for a sample of Spanish small and medium-sized enterprises (SMEs). They use an alternative measure of concentration, the Lerner index, and find support for the market power hypothesis.

Most research on the effect of bank concentration on lending originates from the U.S. Moreover, research has concentrated on privately-held firms, more specifically SMEs, both for the U.S. and other countries. There are solid economic reasons to focus on SMEs: they are smaller, they are more opaque and hence characterized by larger informational asymmetry and they are more dependent on bank financing for their investment than large public firms, suggesting that the effects of bank competition should be more pronounced for SMEs (Berger et al. (2005)). In this study we focus on listed European firms because we use market leverage as the dependent variable, which requires data on the market value of the firms under investigation. We argue that this strategy can yield useful results because European firms, even the larger ones, are still heavily dependent on bank financing. If anything, should we find lending constraints due to the bank market structure for listed firms, this would only strengthen the similar case for SMEs. Another important aspect is the geographical market definition of the banking sector. While studies for the U.S. are able to use more refined concentration measures, we have to rely on country-based measures of bank market structure. However, this geographic 
market definition should not introduce a bias, because for most firms the country level can be considered as the relevant market. Numerous studies have investigated the level of financial integration in Europe and although there is considerable progress in some segments, the banking markets are found to be not fully integrated (Baele et al. (2004)). Furthermore, if the European market were completely integrated, this would work against finding an effect of country-specific bank concentration on the capital structure of non-financial firms. Not only the size of the firm is important, the size of banks has also been found to impact the lending behavior of banks. Berger et al. (2005) find that bigger banks are more apt to lend to firms that are larger or that have better accounting records. It should be noted that the firms in their study are also relatively small. The biggest firms in their study are the smallest firms in our sample. Therefore, it is not clear whether we can assume that the results of Berger et al. (2005) carry over to our sample of listed firms.

The main property of bank lending for the information-based hypothesis is relationship lending, which is seen as the raison d'être of banks since relationships may mitigate informational asymmetries (Diamond (1984), James (1987)). Ongena and Smith (2000) document large cross-country variation in the average number of bank relationships in large firms across 20 European countries. Firms maintain more relationships in countries with unconcentrated but stable banking systems and active bond markets. However, there has been no consensus on the effect of bank concentration on relationship lending (Boot (2000)). Chan et al. (1986) argue that more competition in the banking market implies less relationship banking, since borrowers might be tempted to switch to other banks or to the bond or stock market. Banks then anticipate that relationships have a shorter lifespan and invest less in relationships. A 
complementary negative effect of competition on relationship banking may come from the impact of competition on the intertemporal pricing of loans. Increased credit market competition could impose constraints on the ability of borrowers and lenders to share surpluses intertemporally. Therefore, banks will not fund young corporations (Petersen and Rajan, 1995). This suggests that competition leads to less lending. An alternative view is that competition may elevate the importance of relationships as a distinct competitive edge. Boot and Thakor (2000) show that a relationship orientation can alleviate pressure on profit margins. As a relationship banking orientation can make a bank more unique relative to competitors, interbank competition may increase the value of relationship banking. Hence theory does not provide a consensus on the interaction between relationship lending and concentration.

The market power and information-based hypotheses focus on the supply of bank loans. However, in our empirical setup, we control explicitly for the demand of external finance and incorporate the firm characteristics which have been found in the corporate finance literature to explain capital structure behavior. While the predictions of these characteristics are discussed in the next section, we now examine those firm properties, namely collateral and size, which have been found to interact with bank concentration. Collateral is closely related to relationship lending as bank loan contracts can easily accommodate collateral requirements. An extensive theoretical literature shows that collateral can mitigate moral hazard and adverse selection problems in loan contracting (Shan and Thakor (1987), Stiglitz and Weiss (1981)). However, collateral is likely to be effective only if its value can be monitored (Rajan and Winton (1995)). Besanko and Thakor (1987) show that competition lowers the rents of lenders and suggest that the use of collateral is more likely with 
competition than monopoly. However, bank concentration does not seem to alter the lender's incentives to invest in information. Where the theoretical literature provides no consensus, empirical work by Jimenez, Salas \& Saurina (2006) suggests that there is a negative relationship between collateral and bank concentration. Finally, while the relevant market definition for European firms is the country level, we expect that the largest firms in our sample will have a truly European scope and bank concentration on the country level will therefore not impact those firms. As a result, we conjecture that the interaction between bank concentration and size will have the opposite sign of the effect of bank concentration.

In our empirical setup we also account for the alternatives to bank loans, i.e. market-based corporate financing such as bonds and equity. Rajan and Zingales (1995) examine large companies and find that the firm characteristics that explain capital structure in the U.S. also explain leverage in the other countries. While they find that whether companies are from a bank-based or a market-based country does not affect the level of leverage, their results suggest that bank versus market orientation leads to differences in the relative amounts of private financing (bank loans) and arms-length financing through market securities. However, the importance of banking markets has been found to affect the level of leverage. Demirgüç-Kunt, and Maksimovic (1999) use the ratio of the domestic assets of deposit banks to GDP to examine the impact of access to financial intermediaries and find that countries with larger banking systems have lower ratios of corporate net fixed assets to total assets. They further argue that differences in the financial institutions between countries affect non-financial firms' leverage. Fan, Titman, and Twite (2006) use the supply of funds that are available to the banking sector, assuming that the 
amount of funds that flows to the banking sector can be viewed as exogenous. They find that the bank sector influences the capital structure choice of firms as banks prefer offering their borrowers shorter maturity debt. Finally, Giannetti (2003) examines both listed and unlisted companies from eight countries in the EU for the period 1993-1997. The measures of the development of the financial markets, which includes a measure for bank concentration, are argued to proxy not only for the availability of equity and market debt in a country, but also to be indirect measures of the importance of banks. She finds that bank concentration has a significant negative impact on firm debt, "perhaps in order to escape banks' market power" (p. 208).

\section{Empirical strategy}

Faulkender and Petersen (2006) argue that information asymmetry and agency problems are the market frictions that make capital structure choices relevant but also imply that firms are sometimes rationed by their lenders. Thus, when explaining a firm's leverage, it is important to include not only the determinants of its preferred leverage (the demand side) but also the variables that measure the constraints on a firm's ability to increase its leverage (the supply side). Therefore, we follow their empirical strategy, since we focus our analysis on one particular supply side factor, i.e. bank market structure. To examine the role of credit constraints and help explore the difference between the public debt markets (e.g., bonds) and bank debt, we consider the leverage of firms to be a function of the concentration in the bank market and alternatives to bank loans such as (the development of) the bond market and the equity market. The observed level of debt is a function of the supply of 
debt and the firm's demand for debt, both of which depend on the price of debt capital and supply and demand factors.

$$
\begin{gathered}
Q_{\text {demand }}=\alpha_{0} \text { Price }+\alpha_{1} X_{\text {demand factors }}+\varepsilon_{\text {demand }} \\
Q_{\text {supply }}=\beta_{0} \text { Price }+\beta_{1} X_{\text {supply factors }}+\varepsilon_{\text {supply }}
\end{gathered}
$$

If there are no supply frictions, firms can borrow as much debt as they want (at the correct price), and the observed level of debt will equal the demanded level. This is the traditional assumption in the empirical capital structure literature. Only demand factors explain variation in the firms' debt levels, where demand factors are any firm characteristic that raises the net benefit of debt.

However, if firms without access to public debt markets are constrained in the amount of debt that they may issue (private lenders do not fully replace the lack of public debt), or when they face concentrated banking markets, they will have lower leverage ratios, even after controlling for the firm's demand for debt. Equating the demand and supply, we can express the above equations as two reduced form equations - one for quantity and the other for price - so that each is a function of the demand and supply factors.

$$
Q_{\text {observed }}=\gamma_{D} X_{\text {demand factors }}+\gamma_{S} X_{\text {supply factors }}+\mu
$$

We use a measure of bank market structure or bank conduct to capture the external financing constraints imposed by the access to bank loans. As stated 
before, theory provides mixed arguments leading to two opposing hypotheses. On the one hand, higher bank market concentration may lead to more bank financing under the information-based hypothesis. On the other hand, concentration may be associated with less bank financing when the market power hypothesis holds. We control for two alternatives, bond financing and equity issuing. We expect that bond financing will be positively linked with leverage since firms can turn to the financial markets if the bond market is well developed. With respect to equity issuing, firms will be able to issue equity more easily if the stock market is well developed. As a result they will have lower leverage.

The demand factors are captured by the firm characteristics. Several factors have been found to have a robust correlation with cross-sectional differences in leverage (Frank and Goyal (2005)). Leverage is positively related to tangibility, size and median industry leverage, whereas it is negatively related to growth opportunities and profitability. Tangibility captures the presence of fixed assets which are easier to collateralize. Therefore, firms remain more valuable when they go into distress, hence firms with a lot of collateralizable assets will find it easier to obtain bank loans. Furthermore, the agency costs for firms with high tangible asset ratios are lower, as collateral makes it more difficult for shareholders to substitute high-risk assets for low-risk ones. The next factor is size. Large firms will have more debt since larger firms are more diversified and have lower default risk. Larger firms are also typically more mature firms that have a reputation in debt markets and consequently face lower agency cost of debt. Finally, median industry leverage reflects a number of otherwise omitted common factors and in a trade-off setting, the industry median debt ratio is likely to be a proxy for the target capital structure. The growth opportunities 
of the firm are negatively correlated with leverage since growing firms are assumed to lose more of their value when they go into distress. Furthermore agency costs, which can arise due to underinvestment, asset substitution or free cash flow are mitigated to a large extent in growth firms. Finally, the negative correlation found for firm profitability is usually ascribed to lower expected bankruptcy costs and more valuable interest tax shields. Firms that generate higher profits relative to investments also benefit form the discipline that debt provides in mitigating the free cash flow problem (agency cost). In our empirical setup, we include all these 'stylized' demand factors (Rajan and Zingales (1995), Fama and French (2002), Flannery and Rangan (2006)) next to the supply effect of bank market concentration to explain the variation in corporate leverage.

\section{Data}

The sample of non-financial firms is constructed from Amadeus, a panEuropean financial database that provides detailed balance sheet and income data for companies in Europe and standardized balance sheet information with the stated objective of achieving uniformity and enabling cross-border analysis. We select all consolidated ${ }^{2}$ listed firms of the EU15 for the period

$\overline{2}$ Except for Greece where no consolidated data is available. We also run the regressions without Greece, the results remain unaltered. 
1996-2005 ${ }^{3}$. This sample of firms is merged with market data from Datastream, we use the ISIN code of the firm as identifier. To reduce the impact of outliers we winsorize the sample at the 1st and 99th percentile. We delete all observations for which one of the variables is missing, this leads to the exclusion of firms from Denmark for which no loan data is available and the firms from Luxembourg for which no data on private bond capitalization is available $^{5}$. The final sample is an unbalanced sample of 3364 firms and 19735 firm-year observations. Table 1.A presents an overview of the firm-specific variables used in our empirical analysis to capture the demand side together with their sources. The construction of the variables is standard in the literature (Rajan and Zingales (1995), Flannery and Rangan (2006)). The dependent variable used in the analysis is market leverage which is constructed as the ratio of debt, both short and long term, over the sum of debt and market value of the firm (Flannery and Rangan (2006)). We also use book leverage, defined as the ratio of debt over total assets, but this leads to similar qualitative results.

The supply side is measered using several indicators of bank concentration and bank conduct at the country level (Table 1.B), as well as alternative sources of external finance (Table 1.C). The ECB provides yearly concentration figures for the EU15 from 1997 onwards in their reports on EU bank-

$\overline{3 \text { From }}$ this sample we exclude all financial firms with NACE Rev 1.1 code 65 'Financial intermediation, except insurance and pension funding', 66 'Insurance and pension funding, except compulsory social security', 67 'Activities auxiliary to financial intermediation' and regulated firms, NACE Rev 1.1 code 75 'Public administration and defense; compulsory social security'.

4 We use several updates of Amadeus to mitigate attrition problems.

5 When we include both countries in the base regressions, the results remain the same. 
ing structure (ECB, EU Banking Structures, 2007). The first measure is the Hirschmann-Herfindahl index (HHI), calculated as the sum of the squares of the credit institutions' market shares, according to total assets. Our second measure is the CR5, which is the share of the 5 largest credit institutions in total assets in each country. The HHI ranges from 0 to 10000 where 0 indicates perfect competition and 10000 would indicate a monopoly. The assumption is that concentration leads to less competition as there are less players in the market and therefore, the remaining players can exercise market power.

However, banks are special in nature and it has been suggested that the standard paradigm, that higher concentration leads to market power (Bain (1956)), may not be appropriate for the banking industry (see Degryse and Ongena (2005)). Due to asymmetric information inherent in bank lending, banking competition may have a 'special nature' (Carletti (2005)). Therefore, in addition to HHI and CR5, which are well known and widely used concentration measures, we use two alternatives measures of the observable competitive behavior of banks, i.e. the Lerner index and the Boone indicator, as robustness checks. The Lerner index is intended to measure the degree of competition based on the observed pricing behavior of banks (the indicator is calculated as (price - marginal cost)/price). The index can take values between 0 and 1 , where zero stands for perfect competition and 1 for monopoly power. Therefore, a positive sign would lend support for the information-based hypothesis whereas a negative sign would provide support for the market power hypothesis. Using the Lerner index, Fernández de Guevera et al. (2007) find support for a negative relationship between concentration and competition. Fernández De Guevara and Maudos (2004) calculate this measure for all the countries in our sample, however only until 2000. The Boone indicator measures the 
effect of efficiency in terms of marginal cost on market shares. The rationale is that competition enhances the performance of efficient firms (lower marginal cost) which will lead to higher market shares. Moreover, this effect is assumed to be positively correlated with competition, hence the stronger competition is, the more negative the Boone indicator will be. Therefore, the interpretation of the impact of the measure will be similar to that of the Lerner index where a positive (negative) impact lends support to the information-based hypothesis (market power hypothesis). Van Luevensteijn, Bikker, van Rixtel and Kok-Sørensen (2007) apply the measure to the banking market and single out the behavior of commercial banks, which are the most relevant banks when considering the financing of listed firms. The Boone indicator is available for France, Germany, Italy, Spain, Netherlands and UK for the period 1997 to 2004. Therefore, all large countries in our sample are accounted for together with one of the countries that has the highest concentration in terms of HHI and $\mathrm{CR} 5{ }^{6}$.

Alternative sources to bank financing are included using three indicators of financial market development; two are obtained from the Financial Development and Structure database of the World Bank and one from Datastream. We use private bond market capitalization to GDP, calculated as the ratio of private domestic debt securities as a share of GDP, as a proxy for the development of the bond market, and a measure of stock market development, i.e. the

$\overline{6}$ An alternative measure of bank behavior would be the Panzar-Rosse measure. Bikker and Haaf (2002) calculate this H-statistic for 23 European and non-European countries and find support for the conventional view that concentration impairs competition. However, we lack sufficient data for this measure to apply it in our panel data framework. 
value of listed shares to GDP to proxy for the development of stock markets. Our final measure of access to external finance is obtained checking firm by firm whether they issue bonds using the bond module in Datastream. This provides us with a dummy which has value one starting from the year that the firm issues a bond. We include this dummy to explicitly account for one particular outside financing option using the fact that some firms effectively use bond financing, whereas others do not.

Finally, we include robustness measures (Table 1.D) such as a contestability measure of national bank markets in order to capture the potential competition banks face in their home markets. This approach is supported by Claessens and Laeven (2004) who find no evidence that bank sector concentration has a negative effect on competition in a sample of 50 countries, but report that contestability determines effective competition. The measure of contestability is the share of total assets of foreign branches and subsidiaries relative to the total assets of the banking sector in a particular country. Total bank assets are obtained from the ECB report on banking structures (2007). The relative size of foreign branches and subisiduaries measures the incidence of foreign entry of banks, which should increase the pressure on the incumbent banks to behave more competitively. Hence, we expect a positive impact of contestability on the leverage of non-financial firms.

In table 2, column 1 and 2, we report the mean of the two concentration measures (HHI and CR5) for the period 1997-2005 and their percentage change between 1997 and 2005 in each country in the sample. There is considerable heterogeneity among the European countries. Moreover, the percentage change in HHI between 1997 and 2005 is positive in almost all countries, reflecting a considerable amount of consolidation in the banking industry, be it at different 
speeds. Column 3 and 4 show that there is again a considerable degree of heterogeneity over countries for private bond market capitalization. However, there is no clear relation between the relative size of the country and the importance of its bond market. The relative stock market capitalization also differs across countries, where the bigger countries tend to have the most developed equity markets. The mean values of dummy bond across countries in column 5 indicate that there is a large dispersion in terms of effective bond market use by firms, but also that bond issuing is still only a possibility for a small number of firms. Moreover, when we subdivide the firms in the sample in deciles according to market value, $66.44 \%$ of the firms that have issued bonds are larger than the 70th percentile.

The summary statistics of the firm variables are presented in table 3 . We find substantial cross-sectional variation in both market and book leverage. The average leverage ratio is 26.6 percent with a median of 21.1 percent. There is both variation across countries and across firms within each country. The summary statistics are comparable to the numbers reported in previous research, predominantly with US data (Rajan and Zingales (1995), Giannetti (2003), Flannery and Rangan (2006)). The table also shows cross-sectional variation in the country-level variables. Our main variable of interest, HHI, has a mean of 0.6 but an equally large standard deviation. Over the period considered the HHI ranges from a minimum of 0.114 tot a maximum of 2.73, indicating the co-existence of bank markets with a high and low degree of concentration. The alternative measure for bank market concentration, CR5, ranges from 0.17 to 0.88 . The smallest countries typically have more concentrated banking markets. Moreover, the size of firms may have an impact on external financing behavior. If the distribution of the firms according to size 
would show that the small countries have typically more small firms than big firms relative to big countries, there could be a size bias. Table 4 shows the sample divided into size deciles where the size of the firm is measured by its market value. The first decile represents the smallest firms and the tenth decile the largest firms. In most countries the firms are relatively uniformly spread over the deciles. This distribution of firms across the countries in the sample indicates that any firm size bias should be negligible.

In table 5 the Pearson correlation matrix indicates that multicollinearity should not be a serious problem. The correlations between leverage and the firm characteristics have the expected sign and suggest that profitability and growth opportunities may be negatively correlated with leverage, while size, tangibility and the industry median are positively correlated with leverage. Noteworthy for our analysis, the correlations suggest that the country-level variables may potentially influence the capital structure choice. The correlation of leverage with both concentration measures is negative whereas the measure of private bond market capitization is positive. Stock market capitalization is negatively correlated with market leverage. These raw correlations do not, however, control for other characteristics.

\section{Empirical results}

Our base model is:

$$
\text { leverage }_{i, j, t}=\alpha Z_{i, t-1}+\beta X_{j, t}+\eta_{i}+\delta_{t}+v_{i, j, t}
$$


where the dependent variable is market leverage (when we use book leverage the results remain qualitatively unaltered). $Z_{i, t-1}$ captures the demand side and contains all the firm characteristics that are standard in the empirical corporate finance literature (fixed assets, growth opportunities, size, profitability and industry median leverage). These variables are lagged to alleviate the endogeneity problem. $X_{j, t}$ captures the supply side and contains bank concentration or bank conduct (HHI/CR5/Lerner/Boone), private bond market capitalization over GDP (Private Bond), the stock market capitalization (Stock Market Cap) or a dummy variable taking the value one from the year onwards in which the firm starts issuing bonds (Dummy Bond). We use the subscript $j$ to indicate that these variables, except for Dummy Bond, are at the country level. We use panel corrected standard errors allowing for heterogeneity at the firm level (i.e. Rogers standard errors). ${ }^{7}$ We argue that the fixed effects specification is the relevant one, both from a methodological and an economic point of view. First, including firm fixed effects alleviates the concern of omitted variable bias. Second, when one is interested in partial regression coefficients, holding other effects constant, what matters is whether the effects are independent of the observed regressors or not (Arellano, 2003). In addition, Lemmon, Roberts and Zender (2006) state that, given the importance of unobserved heterogeneity in leverage, parameter estimates that do not account for the firm-specific effect and serial correlation are suspect. Therefore, we use a within transformation by incorporating firm fixed effects and use panel corrected standard errors allowing for heterogeneity at the firm

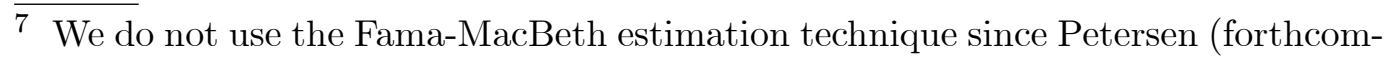
ing) documents that this estimation method is less suited for panels with a large cross-section and small time series.
} 
level (Rogers standard errors) together with year dummies (dummy for 2005 is excluded) to control for serial correlation. Finally, fixed effects at the firm level also allow controlling for industry and/or country effects. Therefore, the firm effects will encompass not only firm-specific characteristics but also those regulatory and macroeconomic conditions in the different countries that do not change over time.

The determinants of leverage

Table 6 presents the basic regressions. In the first column we explain the variation in the market leverage ratio by only including firm characteristics in order to capture the demand side of corporate financing choices. In the second column we introduce the HHI as a measure of bank market concentration in order to take the supply side of bank loans into account. In the third column we also control for alternative sources of finance, i.e. the bond and the stock market. The last three columns show the results when, respectively, CR5, the Lerner index or the Boone indicator are used as an alternative concentration or competition measures.

The first column shows that the coefficients of the firm characteristics have the expected sign and our results are broadly in line with previous findings in the literature (Rajan and Zingales (1995), Giannetti (2003), Fama and French (2002)). Firm profitability has a negative sign and is significant. The market-to-book ratio (proxy for growth opportunities) and depreciation have the expected sign but they are statistically insignificant. Size, tangibility and the industry median have positive and significant coefficients. These findings remain robust throughout the different specifications, indicating that the firmspecific variables capture the demand for external debt finance adequately. The 
question is whether loan supply conditions, captured by the degree of bank market concentration and its evolution over time, have a significant influence on the firms' choice of leverage.

The second column shows that bank market concentration, measured with the HHI, has a significantly negative effect on the observed levels of firm market leverage when included separately. In the third column, we include the proxies for the alternatives to bank financing, the bond and stock market capitalization variables, but the HHI remains negative. This suggests that higher levels of bank market concentration cause a more difficult access of firms to bank loans or may even lead to some degree of credit rationing. This is consistent with the market power hypothesis. Since we account for the demand side of corporate leverage, our results imply that bank consolidation may cause financing constraints, even for the larger firms in the economy. The private bond market capitalization variable is insignificant in this specification. We have to interpret this finding with caution since, even though table 2 indicates that only a small proportion of firms in Europe effectively have access to the bond markets, it is unlikely that more developed bond markets would have no effect on the capital structure choices of all firms. Moreover, the corporate bond market exhibited substantial growth only after the introduction of the Euro in 1999 (we will test for this break later on). The stock market capitalization variable has the expected negative sign: the better developed the stock markets are, the less firms opt to hold debt.

The next three columns present the results with alternatives measures of bank concentration. In column 4 we observe that the CR5 measure of bank market concentration is negative and statistically significant. This corroborates the findings with the $\mathrm{HHI}$, which is not unexpected given the high de- 
gree of correlation between both measures reported in table 5 . In the next two columns we include two behavioral measures for the degree of bank competition, as alternatives for the static market concentration variables. The coefficients for both the Lerner index and the Boone indicator are negative and significant, corroborating the results for the HHI of CR5. The stock market variable remains unaltered, whereas the bond market variables now is significantly positive, as expected. Therefore, the alternative measures for bank market competition confirm the finding that a less competitive bank market structure has a negative effect on firm leverage, which is consistent with the market power hypothesis. Looking at the economic impact of higher bank market concentration on firm leverage, a change of in HHI from the mean, 576 , to the 75 th percentile, 1092 , leads to a decrease in leverage of 4 percentage points. In the literature similar results have been reported (Petersen and Rajan (1994), Zarutski (2006)).

\section{Endogeneity}

A potential problem associated with using observed changes in bank market structure to explain differences in corporate financial structures across countries is that the market structure of the banking sector can itself be influenced by firms' financing decisions or by the development of other institutions, creating a potential endogeneity problem. While an individual firm takes the market structure of the banking sector as given, that market structure may be affected by the aggregate decision of all firms. One plausible explanation could be that companies with higher leverage have higher investment. Hence, these companies will need more external capital, which could trigger the entry of foreign

banks in that country, thereby altering the market structure of the banking sector. To address the endogeneity issue we re-estimate the baseline regres- 
sion using the instrumental variables approach. We follow Fan et al. (2006) and use the size of bank deposits in a country and the amount of non-life insurance premiums as instruments for bank market structure. Demirgüc-Kunt and Maksimovic (1999) propose the country's level of development and its legal system as instruments. However, since we focus on the EU15, our sample is very homogenous in the level of development and it characterized by strong regulatory convergence. As an alternative, we use a dataset from Carletti, Hartmann and Ongena (2007) who constructed indices to capture the various dimensions of competition policy and M\&As (Table 1.E). Carletti et al. (2007) cover both the introduction of competition laws and competition authorities as well as changes in the relative responsibilities of competition and supervisory authorities in bank merger reviews. Moreover, they also document the precise dating of the changes in competition law, allowing time variation in the measures. Carletti et al. (2007) argue that in all cases, the introduction of competition control constituted a significant change for the countries involved. The IV results are presented in table 7 . The first column shows results where bank deposits, non life insurance premium volume and the competition policy measures of Carletti et al. (2008) are used as instruments for HHI. The effect on corporate leverage remains negative, the coefficient is three times larger than in the OLS estimations. In the second column, we include the interaction between HHI and the instruments from column 1 in our instrument set; the results are very similar to our baseline regression. The next columns show that this result remains unaltered for our alternative measures of bank market structure (CR5, the Lerner index and the Boone indicator). All measures confirm the negative and significant effect of bank market structure on leverage. Overall, we can conclude that controlling for endogeneity does not alter the results. 


\section{Robustness}

We apply a number of checks to assess the robustness of our findings. In the first three columns of table 8 we examine the stability of the results across size classes. We split up our sample of firms in quartiles based on the market value of the firms. The results for the firms in the first quartile (relatively small firms) are in column 1, those for the firms in the second and third quartile in column 2 and the findings for the largest firms are presented in column 3. The coefficient estimates indicate that the estimated effects are not robust to differences in size. Whereas the coefficients for the firms in the middle quartiles are similar to those in the full sample estimation, for the quartiles with the smallest and largest firms the bank concentration variable is insignificant. While this can be expected for the largest firms, since they should have easier access to bond financing, it is not clear why bank concentration would lose significance for the smallest firms. However, when we substitute the CR5, Lerner index or Boone indicator for HHI in the first size quartile estimation, the coefficient is significant negative, as in the full sample, corroborating the market power hypothesis. These results indicate that analyzing bank/firm interactions for specific size segments have to be treated with caution. In column 4 we introduce a more refined measure to capture access of firms to the bond market. Dummy Bond is a dummy variable for those firms that have issued bonds, which takes value one starting from the year that the firm taps the bond market. The dummy variable exhibits the expected significant positive effect of bond financing on leverage and the coefficient on bank market concentration becomes insignificant. This confirms the conjecture that the degree of bank market concentration matters less for those firms with effective access to bond financing. This also implies that the further development and 
increased integration of bond markets in Europe may be an effective way of disciplining bank behavior. In columns 5 and 6 of table 8, we examine whether the sample selection or the introduction of the euro have an impact on our results. In column 5, we restrict the sample to firms in the countries included in Gianetti (2003) (Belgium, France, Ireland, Italy, Netherlands, Portugal, Spain and United Kingdom). The coefficients of the firm characteristics are similar to those reported in the baseline regressions. However, the HHI measure of bank market concentration is now insignificant. This shows that the result for bank market concentration may dependent on the selection of countries. We argue that the broader range of countries in our sample is preferable since the larger cross-country variation in the loan supply variable should allow us to estimate the effect on firm leverage more precisely. Moreover, we use market leverage to alleviate the problem of accounting differences in book values of assets. In column 6, a dummy variable taking the value one after 1999 is included. Our intention is to take the introduction of the euro in 1999 and the subsequent development and gradual integration of financial markets into account. This procedure addresses the concern that there might be a structural break in the sample. We also interact this dummy with the concentration measure. The 'Euro' dummy turns out to be positive and significant indicating that European firms increased their leverage after 1999. Whether or not this can be fully attributed to the Euro cannot be established from this simple exercise, since it is also possible that business cycle effects or changes in interest rate conditions may have contributed. The interaction term with HHI is insignificant, indicating that there is no additional effect on leverage that was not already captured by bank market structure itself. However, the bank market concentration variable remains negative and significant, as in the baseline regressions. In the final column of table 8 we include the relative presence 
of foreign banks to account for the contestability of national bank markets. As we expect, this measure has a significant positive impact, suggesting that companies find it easier to get external finance in countries where there is more bank entry. However, the effect of contestability does not compensate the effect of bank concentration; on the contrary, the effect of bank market concentration becomes even more pronounced.

Table 9 contains a number of additional specifications to account for economic or methodological concerns. In the first column we include measures capturing the macroeconomic conditions (GDP growth and inflation) because they may influence the willingness of banks to lend. The coefficient for bank market concentration remains negative and significant. In the specification reported in the second column of table 9 , we run the baseline regression, but exclude those firms which have a zero debt ratio because this choice may be driven by totally different motivations. All results remain unaltered and the significance of the HHI becomes stronger. The next two columns contain two interaction effects. The interaction effect of bank concentration with collateral is insignificant. The interaction with size has a significant positive effect, but the negative effect of bank concentration becomes stronger, hence a larger firm size can only partially alleviate the financial constrainedness. In column 5 of table 9 , we lag the supply variables but the results from the base regression carry over. The final specification in table 9 reports the results from a dynamic estimation as in Flannery and Rangan (2006). This accounts for the argument that firms may face adjustment costs when changing their level of leverage. The lagged leverage variable is instrumented with lagged book leverage and the firm characteristics. Although this procedure constitutes only a first step in applying dynamic estimation, the results for the bank market concentration 
measure remain qualitatively unaltered.

\section{Conclusions}

Credit constraints imposed by banks on firms may hamper economic growth. In this paper we examine whether or not changes in the market structure of European bank markets affect the access of non-financial firms to bank finance. More specifically, we investigate the relationship between the degree of concentration of European bank markets and the capital structure of non-financial firms. In our empirical investigation we confront the information-based and the market power theories, using panel data of 3364 listed firms from the EU15 over the period 1997-2005. During the last decade, the European banking sector has been characterized by a wave of mergers and acquisitions, predominantly in the form of domestic consolidation, leading to a marked increase in the measured level of market concentration in most European countries. Simultaneously, the European bond and stock markets have witnessed a rapid development and a gradually increasing degree of integration since the introduction of the Euro. These developments in the bank and financial markets make the period under consideration, 1997-2005, and the geographical scope (EU15) particularly interesting to investigate the impact of the evolving market structure of financial intermediaries on external financing decisions by non-financial firms.

Overall, our results lend empirical support to the market power hypothesis. We find a negative and significant relationship between the degree of concentration of European bank markets and the market leverage of non-financial

firms. A change in HHI of 100 would lead to a decrease in leverage of 0.8 
percent, which is in line with the results found for SMEs (Petersen and Rajan (1994), Zarutskie (2006)). As the mean over the countries is 576 and the 75 th percentile is 1092 , a change from the mean to the 75 th percentile would mean a drop in leverage of $4 \%$. When we substitute the static bank market structure variables for indicators of bank competition based on the observed behavior of banks, the results remain unaltered. Since we control for endogeniety, alternative sources of external finance and for the firm-specific factors driving the demand for leverage, we are confident that these findings reflect a supply-side effect, implying that the ongoing consolidation of bank markets may impose an external debt finance constraint on non-financial firms. Our results are not consistent with the information-based hypothesis since we find no evidence that banks in more concentrated markets tend to engage in relationship lending, not even with the listed firms in our sample. One possibility for firms would be to use the increasing competition between banks and financial markets to obtain more favorable financing conditions. Our finding that firms with effective access to the bond market are less constrained in their choice of leverage point in this direction. In any case our results imply that the ongoing (domestic) consolidation of the banking industry in Europe can potentially hamper the access of firms to bank financing. From a policy perspective, this calls for renewed efforts to increase the contestability and integration of bank lending markets in Europe.

\section{References}

[1] Arellano, Manuel (2003). Panel Data Econometrics. Oxford, Oxford University Press. 
[2] Baele, Lieven, Annalisa Ferrando, Peter Hördahl, Elizaveta Krylova and Cyril Monnet (2004). "Measuring financial integration in the Euro area." ECB occasional paper series 14 .

[3] Bain, J. (1956). Barriers to New Competition. Cambridge, MA, Harvard University Press.

[4] Beck, Thorsten, Asli Demirgüç-Kunt and Vojislav Maksimovic (2004). "Bank Competition, Financing Obstacles and Access to Credit." Journal of Money, Credit and Banking 36(3): 627-648.

[5] Thorsten Beck, Asli Demirgüç-Kunt and Ross Levine (2000), "A New Database on Financial Development and Structure." World Bank Economic Review 14, 597-605.

[6] Berger, Allen, Asli Demirgüç-Kunt, Ross Levine and Joseph Haubrich (2004). "Bank Concentration and Competition: An Evolution in the Making." Journal of Money, Credit and Banking 36(3): 433-451.

[7] Berger, Allen, Nathan Miller, Mitchell Petersen, Rajan, Raghuram, and Jeremy Stein (2005). "Does Function follow Organisational Form? Evidence from the Lending Practices of Large and Small Banks." Journal of Financial Economics 76: $237-269$.

[8] Besanko, David and Anjan Thakor (1987). "Competitive equilibria in the credit market under asymmetric information." Journal of Economic Theory 42: 167182.

[9] Bester, Helmut (1985). "Screening vs. Rationing in Credit Markets with Imperfect Information." American Economic Review 75(4): 850-855.

[10] Black, Sandra, and Philip Strahan (2002). "Entrepreneurship and Bank Credit Availability." Journal of Finance 57(6): 2807-2833. 
[11] Boot, Arnoud (2000). "Relationship banking: What do we know?" Journal of Financial Intermediation 9: 7-25.

[12] Boot, Arnoud and Anjan Thakor (2000). "Can relationship banking survive competition?" Journal of Finance 55(2): 679-713.

[13] Carbó-Valverde, Santiago, Francisco Rodríguez-Fernández and Gregory Udell (2006). "Bank Market Power and SME Financing Constraints." working paper.

[14] Carletti, Elena, Philipp Hartmann, and Steven Ongena (2008). "The economic impact of merger control legistation.", working paper.

[15] Chan, Yuk-Shee, Stuart Greenbaum and Anjan Thakor (1986). "Information reusability, competition and bank asset quality.", Journal of Banking and Finance 10, 255-276.

[16] Chan, Yuk-Shee and Anjan Thakor (1987). "Collateral and competitive equilibria with moral hazard and private information." Journal of Finance 42 (2): 345-363.

[17] Claessens, Stijn and Luc Laeven (2004). "What drives bank competition? Some international evidence." Journal of Money, Credit and Banking 36(3): 563-583.

[18] Danthine, Jean-Pierre, Francesco Giavazzi and Ernst-Ludwig Von Thadden (2000). "European Financial Markets after the EMU: A First Assessment." NBER working paper w8044.

[19] De Bandt, Olivier and Philip Davis (2000). "Competition, contestability and market structure in European banking sectors on the eve of EMU." Journal of Banking and Finance 24: 1045-1066.

[20] Degryse, Hans and Steven Ongena (2005). "Competition and Regulation in the Banking Sector: A Review of the Empirical Evidence on the Sources of Bank Rents." working paper. 
[21] De Meza, David, and David Webb (2007). "Credit Rationing: Something's Gotta Give." Economica 73: 563-578.

[22] Demirgüç-Kunt, Asli and Vojislav Maksimovic (1999). "Institutions, Financial Markets, and Firm Debt Maturity." Journal of Financial Economics 54: 295-336.

[23] Diamond, Douglas (1984). "Financial intermediation and delegated monitoring." Review of Economic Studies 51(3): 393-414.

[24] ECB (2004). "Report on EU banking structure November 2004."

[25] ECB (2006). "Report on EU banking structure November 2006."

[26] ECB (2007). "Report on EU banking structure November 2007."

[27] Fama, Eugene, and Kenneth French (2002). "Testing Trade-Off and Pecking Order Predictions About Dividends and Debt." Review of Financial Studies 15(1): 1-33.

[28] Fan, Joseph, Sheridan Titman and Garry Twite (2006). "An International Comparison of Capital Structure and Debt Maturity Choices." working paper.

[29] Faulkender, Michael, and Mitchell Petersen (2006). "Does the Source of Capital Affect Capital Structure?" Review of Financial Economics 19(1): 45-79.

[30] Fernández de Guevara, Juan and Joaquím Maudos (2007). "Measuring welfare loss of market power: an application to European banks." Applied Economics Letters 11: 833-836.

[31] Flannery, Mark, and Kasturi Rangan (2005). "Partial Adjustment toward Target Capital Structures." Journal of Financial Economics 79: 469-506.

[32] Frank, Murray, and Vidhan Goyal (2005). "Tradeoff and Pecking Order Theories of Debt." working paper, forthcoming in B.Espen Eckbo (ed.) Handbook of Corporate Finance: Empirical Corporate Finance, Volume B (Handbooks in Finance Series, Elsevier/North-Holland), Chapter 12, 2006. 
[33] Giannetti, Mariassunta (2003). "Do Better Institutions Mitigate Agency Problems? Evidence from Corporate Finance Choices." Journal of Financial and Quantitative Analysis 38: 185-212.

[34] James, Christopher (1987). "Some evidence on the uniqueness of bank loans." Journal of Financial Economics 19(2): 217-235.

[35] Jensen, Michael and William Meckling (1976). "Theory of firm - managerial behavior, agency costs and ownership structure." Journal of Financial Economics 3(4): 305-360.

[36] Jiménez, Gabriel, Vicente Salasa and Jesús Saurina (2006). "Determinants of collateral." Journal of Financial Economics 81: 255-281.

[37] Leary, Mark (2005). "Bank loan supply, lender choice, and corporate capital structure." working paper.

[38] Lemmon, Michael, and Michael Roberts (2007). "The response of corporate financing and investment to changes in the supply of credit." HKUST Business School Research Paper No. 07-29.

[39] Lemmon, Michael, Michael Roberts and Jaime Zender (2006). "Back to the beginning: persistence and the cross-section of corporate capital structure." working paper.

[40] Levine, Ross, and Sara Zervos (1998). "Stock market, banks, and economic growth." American Economic Review 88(3): 537-558.

[41] Modigliani, Franco and Merton Miller (1958). "The Cost of Capital, Corporation Finance, and the Theory of Investment." American Economic Review 48: 261-297.

[42] Myers, Stewart(1984). "The capital structure puzzle." Journal of Finance 39 (3): 575-592. 
[43] Ongena, Steven and David Smith (2000). "What Determines the Number of Bank Relationships? Cross-Country Evidence." Journal of Financial Intermediation 9: 26-56.

[44] Petersen, Mitchell (forthcoming). "Estimating Standard Errors in Finance Panel Data Sets: Comparing Approaches." Review of Financial Studies.

[45] Petersen, Mitchell, and Raghuram Rajan (1994). "The Benefits of Lending Relationships: Evidence from Small Business Data." Journal of Finance 49(1): $3-37$.

[46] Petersen, Mitchell, and Raghuram Rajan (1995). "The Effect of Credit Market Competition on Lending Relationships." Quarterly Journal of Economics 110(2): 407-443.

[47] Rajan, Rahguram and AndrewWinton (1995). "Covenants and collateral as incentives to monitor." Journal of Finance 50: 1113-1146.

[48] Rajan, Rahguram, and Luigi Zingales (1995). "What Do We Know about Capital Structure? Some Evidence from International Data." Journal of Finance 50(5): 1421-1460.

[49] Rajan, Rahguram, and Luigi Zingales (2003). "Banks and markets: The changing character of European Finance." NBER working paper w9595.

[50] Saidenberg, Marc, and Philipp Strahan (1999). "Are Banks still Important for Financing Large Businesses?" Current Issues in Economics and Finance 5, 12, Federal Reserve Bank of New York.

[51] Sapienza, Paola (2002). "The Effects of Banking Mergers on Loan Contracts." Journal of Finance 57(1): 329-369.

[52] Stiglitz, Joseph, and Andrew Weiss (1981). "Credit Rationing in Markets with Imperfect Information." American Economic Review 71(3): 393-410. 
[53] Titman, Sheridan, and Roberto Wessels (1988). "The Determinants of Capital Structure Choice." Journal of Finance 43(1): 1-19.

[54] van Leuvensteijn, Michiel, Jacob Bikker, Adrian van Rixtel, and Christoffer Kok-Sørensen (2007). "A new approach to measuring competition in the Loan Markets of the Euro Area." CPB discussion paper 84 .

[55] Zarutskie, Rebecca (2006). "Evidence on the Effects of Bank Competition on Firm Borrowing and Investment." Journal of Financial Economics 81: 503-537. 
Table 1

Definitions of the variables

Variable

Definition

Source

A. Firm specific variables

Market value of the firm /

Size of the firm

share price * outstanding shares + loans (debt for less than one year) + longtermdebt (debt for more than one year)

Market leverage

Book leverage

Profitability

Growth opportunties

Depreciation

Tangibility

Median industry leverage loans + long term debt / market value of the firm

loans + long term debt / total assets.

Ebit / total assets

Market value of firm / total assets

Depreciation / total assets

Fixed tangible assets / total assets

The firm's industry median debt ratio (using the Fama and French industry classification)

\section{B. Measures of bank market structure}

$\mathrm{HHI}$

CR5

Lerner

Boone indicator

the sum of the squares of the credit institutions' market shares, according to total assets the share of the 5 largest credit institutions in total assets in each country

(price - marginal cost)/price . The index can take values between 0 and 1, where zero stands for perfect competition and 1 for monopoly power.

assumes that competition enhances the performance of efficient frims. The stronger competition is, the more negative the Boone indicator must be.

C. Alternative sources of external finance

Private Bond

Dummy bond

Stock Market Cap

the ratio of private domestic debt securities issued by financial institutions and corporations as a share of GDP

dummy variable which has value one starting from the year that the firm issues a bond the value of listed shares to GDP
Amadeus + Datastream

Amadeus + Datastream

Amadeus

Amadeus

Amadeus + Datastream

Amadeus

Amadeus

Amadeus

ECB

ECB

Fernández De Guevara and Maudos (2004)

van Luevensteijn, Bikker, van Rixtel and Kok-Sørensen (2007)

World Bank

Datastream

World Bank 


\section{Table 1 Continued}

Definitions of the variables

Variable

D. Robustness variables
Definition

The share of total assets of foreign
branches and subsiduaries relative
to the total assets of the whole
banking sector in that particular
country

E. Instrumenting variables

Bank Deposits

Non-life Insurance

Competition policy - criteria

Competition policy - control

Competition policy - third party

Competition policy - notification
Demand, time and saving deposits in deposit money banks as a share of GDP

Nonlife insurance premium volume as a share of GDP

Index ranging from 0 to 1 using assessment criteria that are used in competition control

Index ranging from 0 to 1 using who is (are) the decision-making agency(ies) for competition control Index ranging from 0 to 1 using if a third agency can intervene in the process to replace/overturn the decision-making agency(ies)

Index ranging from 0 to 1 using if merger notification is mandatory above (statutory) thresholds
Source

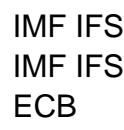

World Bank

World Bank

Carletti, Hartmann and Ongena (2007)

Carletti, Hartmann and Ongena (2007)

Carletti, Hartmann and Ongena (2007)

Carletti, Hartmann and Ongena (2007) 


\section{Table 2}

For the two concentration measures, the first column states the mean for the period 1997-2005,

the second column the percentage change between 1997 and 2005.

$\mathrm{HHI}$ and CR5 are both from the ECB. Private bond and Stock Market Capitalization are from the Financial Development and Structure database of the World Bank. Dummy Bond is a dummy variable which has value one starting form the year that the firm issues a bond.

\begin{tabular}{|c|c|c|c|c|c|c|c|}
\hline & \multicolumn{2}{|c|}{$\mathrm{HHI}$} & \multicolumn{2}{|c|}{ CR5 } & Private bond & Stock Market cap & Dummy Bond \\
\hline & mean & change & mean & change & mean & mean & mean \\
\hline Austria & 0.55 & 9 & 0.44 & 2 & 0.34 & 0.17 & 0.06 \\
\hline Belgium & 1.62 & 202 & 0.76 & 57 & 0.45 & 0.76 & 0.11 \\
\hline Finland & 2.28 & 27 & 0.83 & -6 & 0.24 & 1.3 & 0.07 \\
\hline France & 0.57 & 69 & 0.46 & 35 & 0.41 & 0.77 & 0.16 \\
\hline Germany & 0.16 & 53 & 0.2 & 29 & 0.5 & 0.48 & 0.12 \\
\hline Greece & 1.09 & 24 & 0.65 & 18 & 0.01 & 0.66 & 0.02 \\
\hline Ireland & 0.57 & 20 & 0.45 & 12 & 0.23 & 0.58 & 0.06 \\
\hline Italy & 0.24 & 14 & 0.27 & 8 & 0.38 & 0.46 & 0.15 \\
\hline Netherlands & 1.74 & 9 & 0.83 & 8 & 0.47 & 1.21 & 0.19 \\
\hline Portugal & 0.86 & 100 & 0.56 & 50 & 0.23 & 0.41 & 0.03 \\
\hline Spain & 0.48 & 71 & 0.42 & 31 & 0.17 & 0.65 & 0.08 \\
\hline Sweden & 0.8 & 2 & 0.56 & -2 & 0.42 & 1.09 & 0.06 \\
\hline U.K. & 0.3 & 92 & 0.3 & 50 & 0.17 & 1.46 & 0.18 \\
\hline Total & 0.59 & 53 & 0.42 & 23 & 0.29 & 0.99 & 0.14 \\
\hline
\end{tabular}




\section{Table 3}

Summary statistics

Sample includes all non-financial listed firms from Amadeus (except NACE Rev. 1.165 - 67) which have market in data in Datastream with two or more adjacent years during 1997-2005. Total : 3664 firms, 19735 firm years. All variables are winsorized at the 1 st and 99 th percentiles to avoid the influence of extreme observations.

\begin{tabular}{|c|c|c|c|c|c|c|}
\hline & $\begin{array}{r}\text { Number of } \\
\text { Observations }\end{array}$ & Mean & Median & Std. Dev & Min. & Max. \\
\hline Market Leverage & 19735 & 0.27 & 0.21 & 0.23 & 0 & 0.89 \\
\hline Profitability & 19735 & 0.03 & 0.06 & 0.17 & -0.98 & 0.33 \\
\hline Growth Opportunities & 19735 & 1.27 & 0.89 & 1.32 & 0.18 & 10.33 \\
\hline Depreciation & 19735 & 0.05 & 0.04 & 0.05 & 0 & 0.3 \\
\hline Tangibility & 19735 & 0.29 & 0.23 & 0.23 & 0 & 0.95 \\
\hline Industry Median & 19735 & 0.21 & 0.2 & 0.1 & 0.03 & 0.43 \\
\hline $\mathrm{HHI}$ & 117 & 0.61 & 0.4 & 0.53 & 0.11 & 2.73 \\
\hline CR5 & 117 & 0.42 & 0.36 & 0.19 & 0.17 & 0.88 \\
\hline Lerner & 46 & 0.17 & 0.05 & 0.18 & 0.09 & 0.27 \\
\hline Boone & 31 & -2.53 & -1.69 & 2.84 & -9.36 & 0.63 \\
\hline Private Bond & 117 & 0.29 & 0.23 & 0.16 & 0 & 0.68 \\
\hline Dummy Bond & 19735 & 0.14 & 0 & 0.34 & 0 & 1 \\
\hline GDP Growth & 117 & 2.58 & 2.7 & 1.27 & -0.7 & 9.4 \\
\hline Inflation & 117 & 1.83 & 1.76 & 0.89 & 0.14 & 5.43 \\
\hline
\end{tabular}


Table 4

Distribution of firms by total assets (percentage)

All firms are pooled and they are placed in deciles according ot their market value. Decile 1 has the smallest firms, decile 10 the largest.

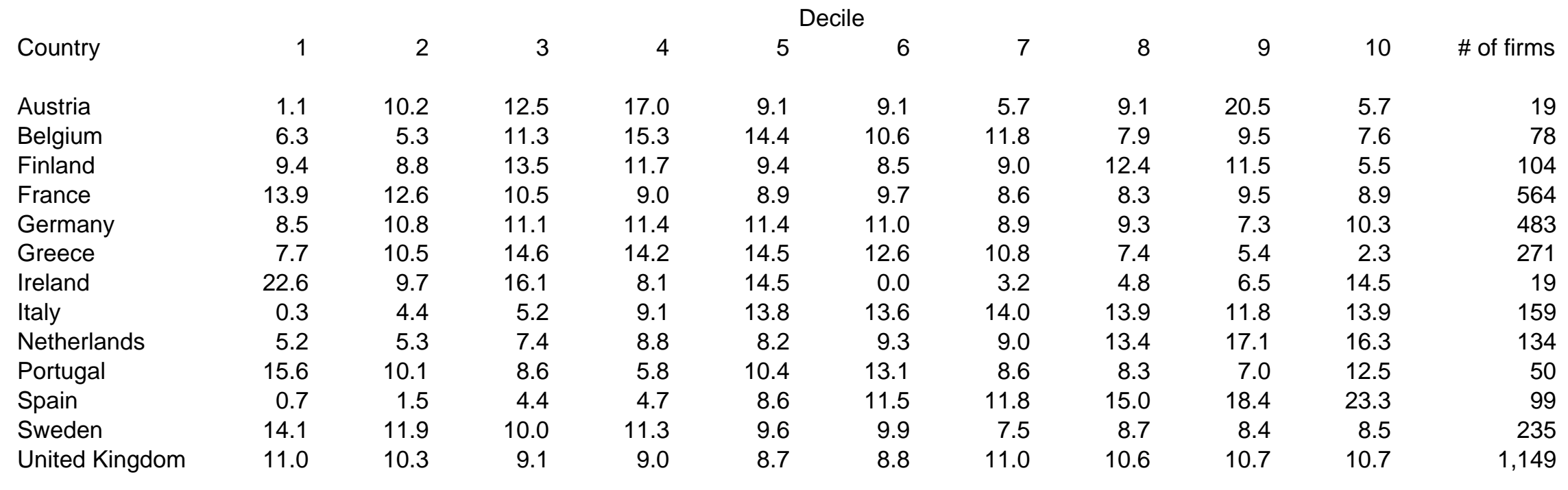


Table 5

Correlation matrix

The table provides Pearson correlation coefficients

[1]

[3]

[4]

[5]

[6]

[7]

[8]

[9]

[10]

Market Leverage

Book Leverage

Size

Profitability

Growth Opportunities

Depreciation

Tangibility

Industry Median

$\mathrm{HHI}$

CR5

Lerner

Boone

Private Bond

Dummy Bond

Stock Market Cap

GDP Growth

Inflation

Contestability

$\begin{array}{rr}\text { [1] } & 1 \\ {[2]} & 0.8357 \\ {[3]} & 0.2321\end{array}$

[4] -0.1952

[5] -0.4797

[6] -0.0097

[7] 0.3056

[8] $\quad 0.334$

[9] -0.0226

[10] -0.0232

[11] -0.0848

[12] -0.0794

[13] 0.0997

[14] 0.1302

[15] -0.1517

[16] -0.0968

[17] 0.0286

[18] -0.0759
0.2082

$-0.103$

$-0.017$

0.0077

0.2918

0.2407

$-0.0078$

$-0.0096$

$-0.0351$

$-0.0854$

0.0117

0.139

$-0.0548$

$-0.0038$

0.0285

$-0.001$
1
0.2198

$-0.1075$

$-0.0778$

0.2274

0.1835

$-0.0607$

$-0.0544$

$-0.0839$

$-0.1539$

0.0975

0.3614

$-0.0543$

$-0.0396$

$-0.0044$

$-0.0979$

\begin{tabular}{l}
1 \\
5 \\
\hline \\
\hline \\
\hline \\
\hline \\
\hline
\end{tabular}

1
0.2284
-0.0967
0.089
0.0276
0.0224
0.0218
-0.0247
0.0716
-0.02
0.0333
0.0699
0.106
-0.0101
0.0443

.

1
0.211
-0.1029
-0.0402
-0.0406
-0.1303
-0.1001
0.2158
-0.0395
-0.0798
-0.1744
-0.0822
-0.1569

1
0.3268
-0.0968
-0.0985
0.0854
-0.2086
-0.0581
0.0847
0.0661
0.0678
-0.0658
0.0734

1
0.0548
0.0569
0.0361
0.0031
-0.0324
0.0637
-0.1413
-0.051
0.095
-0.0654

1
0.9972
-0.0452
0.804
-0.0758
-0.059
-0.0286
0.2615
0.4058
-0.1456

Boone

Private Bond

Dummy Bond

Stock Market Cap

GDP Growth

Inflation

$\begin{array}{rr} & {[12]} \\ {[12]} & 1 \\ {[13]} & -0.2113 \\ {[14]} & 0.0593 \\ {[15]} & 0.6108 \\ {[16]} & 0.1854 \\ {[17]} & 0.3252 \\ {[18]} & 0.7083\end{array}$

$$
[14]
$$

[15]

[16]

[17]

$[18$

Contestability

[18] 0.7083

0.0065

$-0.3341$

$-0.4764$

$-0.1606$

$-0.6658$

0.0718

$-0.0398$

$-0.062$

0.0627

1
0.3431
-0.3193
0.6099

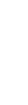

1

$0.3266-0.2261$
1
-0.0587

$-0.5639$

$-0.0017$

0.6939

0.1065

$-0.0375$

0.5975 
Table 6

Baseline regression

\begin{tabular}{|c|c|c|c|c|c|}
\hline [1] & [2] & [3] & [4] & [5] & {$[6$} \\
\hline & $\mathrm{HH}$ & & CR5 & Lerner & Boone \\
\hline
\end{tabular}

Profitability

$\begin{array}{rrrrrr}-0.175 & -0.173 & -0.172 & -0.173 & -0.135 & -0.257 \\ 10.55]^{* *} & {[10.44]^{* *}} & {[10.36]^{* *}} & {[10.41]^{* *}} & {[4.74]^{* *}} & {[7.27]^{* *}} \\ -0.012 & -0.012 & -0.012 & -0.012 & -0.007 & -0.013 \\ {[9.42]^{* *}} & {[9.31]^{* *}} & {[9.22]^{* *}} & {[9.25]^{* *}} & {[3.05]^{* *}} & {[6.31]^{* *}} \\ 0 & 0.002 & -0.001 & -0.003 & 0.11 & 0.069 \\ {[0.01]} & {[0.04]} & {[0.01]} & {[0.06]} & {[1.10]} & {[0.74]} \\ 0.033 & 0.032 & 0.032 & 0.032 & 0.001 & 0.054 \\ {[6.40]^{* *}} & {[6.32]^{* *}} & {[6.27]^{* *}} & {[6.37]^{* *}} & {[0.20]} & {[5.87]^{* *}} \\ 0.146 & 0.148 & 0.149 & 0.146 & 0.107 & 0.096 \\ {[5.99]^{* *}} & {[6.05]^{* *}} & {[6.09]^{* *}} & {[5.99]^{* *}} & {[4.06]^{* *}} & {[2.33]^{*}} \\ 0.224 & 0.227 & 0.23 & 0.226 & 0.131 & 0.117 \\ {[5.51]^{* *}} & {[5.62]^{* *}} & {[5.70]^{* *}} & {[5.60]^{* *}} & {[2.43]^{*}} & {[2.07]^{*}} \\ & -0.084 & -0.089 & & & \end{array}$

$[5.23]^{* *} \quad[5.35]^{* *}$

CR5

$-0.424$

$[6.33]^{\star *}$

Lerner

Boone

Private Bond

Stock Market Cap

Observations

Number of group (firm)

R-squared
19735

3364

0.14
[6] 
Table 7

Endogeneity

\begin{tabular}{|c|c|c|c|c|c|}
\hline & \multicolumn{2}{|r|}{ [2] } & [3] & [4] & \multirow{2}{*}{ [5] } \\
\hline & $\mathrm{HH}$ & & CR5 & Lerner & \\
\hline \multirow[t]{2}{*}{ Profitability } & -0.163 & -0.167 & $\begin{array}{r}-0.169 \\
\end{array}$ & -0.124 & -0.26 \\
\hline & $(10.68)^{\star \star}$ & $(10.98)^{\star \star}$ & $(11.06)^{* *}$ & $(4.19)^{\star *}$ & $(6.64)^{\star *}$ \\
\hline \multirow[t]{2}{*}{ Growth Opportunities } & -0.011 & -0.012 & -0.012 & -0.007 & -0.013 \\
\hline & $(9.21)^{\star \star}$ & $(9.70)^{\star \star}$ & $(9.73)^{\star *}$ & $(2.79)^{\star *}$ & $(5.79)^{\star \star}$ \\
\hline \multirow{2}{*}{ Depreciation } & 0 & -0.004 & -0.006 & 0.092 & 0.089 \\
\hline & -0.01 & -0.08 & -0.11 & -0.86 & -0.9 \\
\hline \multirow[t]{2}{*}{ Size } & 0.03 & 0.031 & 0.032 & 0.006 & 0.058 \\
\hline & $(6.28)^{* *}$ & $(6.52)^{\star *}$ & $(6.68)^{\star *}$ & -0.72 & $(6.05)^{\star *}$ \\
\hline \multirow[t]{2}{*}{ Tangibility } & 0.152 & 0.15 & 0.145 & 0.113 & 0.094 \\
\hline & $(6.60)^{* *}$ & $(6.58)^{\star *}$ & $(6.40)^{\star \star}$ & $(4.08)^{\star *}$ & $(2.17)^{\star}$ \\
\hline \multirow[t]{2}{*}{ Industry Median } & 0.253 & 0.245 & 0.24 & 0.144 & 0.13 \\
\hline & $(6.61)^{* *}$ & $(6.44)^{\star *}$ & $(6.30)^{\star *}$ & $(2.38)^{*}$ & $(2.09)^{*}$ \\
\hline $\mathrm{HHI}$ & $\begin{array}{r}-0.316 \\
(319)^{* *}\end{array}$ & $\begin{array}{r}-0.12 \\
(733)^{* *}\end{array}$ & & & \\
\hline CR5 & & & $\begin{array}{r}-0.592 \\
(8.97)^{\star *}\end{array}$ & & \\
\hline Lerner & & & & $\begin{array}{r}-1.558 \\
(9.49)^{\star *}\end{array}$ & \\
\hline Boone & & & & & $\begin{array}{r}-0.013 \\
(7.13)^{\star *}\end{array}$ \\
\hline \multirow[t]{2}{*}{ Private Bond } & -0.025 & -0.017 & -0.032 & 0.474 & 0.165 \\
\hline & -0.72 & -0.5 & -0.9 & $(5.66)^{\star *}$ & $(3.35)^{\star *}$ \\
\hline \multirow[t]{2}{*}{ Stock Market Cap } & -0.049 & -0.034 & -0.029 & -0.054 & -0.315 \\
\hline & $(3.81)^{\star *}$ & $(3.55)^{\star *}$ & $(3.01)^{\star *}$ & $(3.42)^{\star *}$ & $(6.65)^{\star *}$ \\
\hline Observations & 18700 & 18700 & 18700 & 5344 & 5843 \\
\hline Number of group (firm) & 3356 & 3356 & 3356 & 1738 & 1282 \\
\hline R-squared & 0.13 & 0.14 & 0.14 & 0.16 & 0.23 \\
\hline
\end{tabular}

Robust t statistics in brackets

* significant at $5 \%$; ** significant at $1 \%$

Endogeneity results for specification (4)

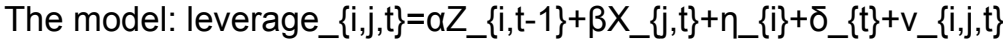

All regressions include firm fixed effects and year dummies (dummy for 2005 is excluded) and have standard errors which are corrected for heteroskedasticity, and clustering at the firm level (Rogers standard errors)

The firm characteristics are lagged one period to alleviate problems of endogeneity.

All regressions are estimated using IV to instrument bank market structure

[1] the insturmentset includes bank deposits / GDP, non life insurance premium volume / GDP and the competition policy measures of Carletti et al. (2008)

[2]-[5] the insturmentset includes bank deposits / GDP, non life insurance premium volume / GDP and the competition policy measures of Carletti et al. (2008) plus the interaction of the bank market structure measure with the aforementioned instruments 
Table 8

Robustness

\begin{tabular}{|c|c|c|c|c|c|c|c|}
\hline & [1] & [2] & [3] & [4] & [5] & [6] & [7] \\
\hline \multirow[t]{2}{*}{ Profitability } & -0.105 & -0.153 & -0.162 & -0.31 & -0.168 & -0.172 & -0.172 \\
\hline & {$[4.48]^{\star *}$} & {$[6.79]^{* *}$} & {$[3.66]^{\star *}$} & {$[5.84]^{\star *}$} & {$[8.53]^{\star *}$} & {$[10.35]^{\star *}$} & {$[11.38]^{* *}$} \\
\hline \multirow[t]{2}{*}{ Growth Opportunities } & -0.005 & -0.005 & -0.003 & -0.013 & -0.011 & -0.012 & -0.012 \\
\hline & [1.51] & {$[3.27]^{\star *}$} & [1.77] & {$[3.33]^{\star *}$} & {$[6.86]^{\star *}$} & {$[9.22]^{* *}$} & {$[10.01]^{\star *}$} \\
\hline \multirow[t]{2}{*}{ Depreciation } & 0.07 & -0.136 & -0.114 & 0.118 & 0.043 & -0.001 & 0.003 \\
\hline & [0.73] & {$[1.71]$} & {$[0.97]$} & [0.69] & [0.65] & {$[0.01]$} & [0.06] \\
\hline \multirow[t]{2}{*}{ Size } & 0.064 & 0.058 & 0.042 & 0.046 & 0.032 & 0.032 & 0.032 \\
\hline & {$[4.90]^{\star *}$} & {$[7.59]^{\star \star}$} & {$[4.86]^{\star *}$} & {$[3.78]^{\star *}$} & {$[5.73]^{\star *}$} & {$[6.27]^{\star *}$} & {$[6.83]^{* *}$} \\
\hline \multirow[t]{2}{*}{ Tangibility } & 0.139 & 0.131 & 0.102 & 0.054 & 0.13 & 0.149 & 0.148 \\
\hline & {$[3.22]^{\star *}$} & {$[3.82]^{* *}$} & {$[2.55]^{*}$} & {$[0.79]$} & {$[4.67]^{* *}$} & {$[6.10]^{\star *}$} & {$[6.70]^{\star *}$} \\
\hline \multirow[t]{2}{*}{ Industry Median } & 0.017 & 0.287 & 0.105 & 0.198 & 0.156 & 0.23 & 0.218 \\
\hline & {$[0.17]$} & {$[5.46]^{* *}$} & {$[1.76]$} & {$[2.32]^{*}$} & {$[3.65]^{* *}$} & {$[5.69]^{* *}$} & {$[6.01]^{* *}$} \\
\hline \multirow[t]{2}{*}{$\mathrm{HHI}$} & -0.055 & -0.084 & 0.011 & -0.034 & 0.008 & -0.09 & -0.127 \\
\hline & [1.43] & {$[4.06]^{* *}$} & {$[0.40]$} & {$[0.93]$} & {$[0.37]$} & {$[4.81]^{\star *}$} & {$[7.19]^{* *}$} \\
\hline \multirow[t]{2}{*}{ Private Bond } & -0.141 & 0.059 & 0.108 & & 0.169 & -0.003 & 0.015 \\
\hline & {$[1.44]$} & {$[1.16]$} & {$[1.97]^{*}$} & & {$[3.50]^{\star *}$} & {$[0.09]$} & [0.48] \\
\hline \multirow[t]{2}{*}{ Stock Market Cap } & 0.003 & -0.034 & 0.001 & 0.028 & 0.009 & -0.028 & -0.018 \\
\hline & {$[0.10]$} & {$[2.33]^{*}$} & [0.03] & [0.89] & [0.57] & {$[2.68]^{* *}$} & [1.93] \\
\hline \multirow[t]{2}{*}{ Dummy Bond } & & & & 0.038 & & & \\
\hline & & & & {$[2.42]^{*}$} & & & \\
\hline \multirow[t]{2}{*}{ HHIEuro Dummy } & & & & & & 0.001 & \\
\hline & & & & & & {$[0.11]$} & \\
\hline \multirow[t]{2}{*}{ Euro dummy } & & & & & & 0.047 & \\
\hline & & & & & & {$[5.01]^{* *}$} & \\
\hline \multirow[t]{2}{*}{ Contestability } & & & & & & & 0.22 \\
\hline & & & & & & & {$[7.27]^{\star *}$} \\
\hline Observations & 5229 & 9237 & 5269 & 3175 & 13552 & 19735 & 19735 \\
\hline Number of group (firm) & 1499 & 2246 & 1131 & 479 & 2252 & 3364 & 3364 \\
\hline R-squared & 0.09 & 0.17 & 0.19 & 0.23 & 0.14 & 0.14 & 0.15 \\
\hline
\end{tabular}

Robust t statistics in brackets

${ }^{*}$ significant at $5 \% ;{ }^{* *}$ significant at $1 \%$

Robustness results for specification (4)

The model: leverage_ $\{i, j, t\}=\alpha Z \_\{i, t-1\}+\beta X \_\{j, t\}+\eta \_\{i\}+\delta \_\{t\}+v \_\{i, j, t\}$

The dependent variable is market leverage

All regressions include firm fixed effects and year dummies (dummy for 2005 is excluded)

and have standard errors which are corrected for heteroskedasticity, and clustering at the

firm level (Rogers standard errors)

The firm characteristics are lagged one period to alleviate problems of endogeneity.

[1]-[3] check for stability across size where [1] are the firms in quartile 1 of total assets,

[2] firms in quartile $2+3$ and [3] firms in quartile 4

[4] uses only those firms that have issued a bond

[5] uses the sample of countries of Giannetti

[6] the introduction of the euro

[7] control for contestability 
Table 9

Robustness continued

[1] [2]

[3]

[4]

[5]

[6]

Lagged Market Leverage

$\begin{array}{rrrrrr} & & & & & 0.526 \\ -0.173 & -0.193 & -0.172 & -0.17 & -0.177 & {[32.30]^{* *}} \\ {[10.41]^{* *}} & {[10.55]^{* *}} & {[10.37]^{* *}} & {[10.24]^{* *}} & {[9.46]^{* *}} & {[7.90]^{* *}} \\ -0.012 & -0.014 & -0.012 & -0.012 & -0.011 & 0 \\ {[9.29]^{* *}} & {[9.33]^{* *}} & {[9.24]^{* *}} & {[9.27]^{* *}} & {[6.92]^{* *}} & {[0.30]} \\ 0.009 & 0.017 & -0.001 & 0.007 & -0.046 & -0.029 \\ {[0.15]} & {[0.27]} & {[0.02]} & {[0.12]} & {[0.70]} & {[0.64]} \\ 0.034 & 0.03 & 0.032 & 0.021 & 0.031 & 0.008 \\ {[6.58]^{* *}} & {[5.70]^{* *}} & {[6.29]^{* *}} & {[3.55]^{* *}} & {[4.94]^{* *}} & {[2.24]^{*}} \\ 0.145 & 0.133 & 0.12 & 0.151 & 0.134 & 0.053 \\ {[5.95]^{* *}} & {[5.30]^{* *}} & {[3.63]^{* *}} & {[6.16]^{* *}} & {[4.79]^{* *}} & {[3.30]^{* *}} \\ 0.237 & 0.226 & 0.231 & 0.224 & 0.235 & 0.009 \\ {[5.87]^{* *}} & {[5.46]^{* *}} & {[5.70]^{* *}} & {[5.54]^{* *}} & {[5.11]^{* *}} & {[0.35]} \\ -0.086 & -0.096 & -0.107 & -0.466 & -0.076 & -0.051 \\ {[5.16]^{* *}} & {[5.54]^{* *}} & {[5.28]^{* *}} & {[4.16]^{* *}} & {[3.97]^{* *}} & {[4.68]^{* *}}\end{array}$

$\mathrm{HHI}{ }^{*}$ Tangibility

0.055

[1.34]

$\mathrm{HHI}$ Size

0.02

$[3.41]^{* *}$

Private Bond

$\begin{array}{ll}-0.003 & -0.002\end{array}$

0.001

$-0.009$

0.076

0.065

[0.08]

[0.07]

[0.04]

[0.27]

$[1.74] \quad[3.06]^{* *}$

Stock Market Cap

$-0.037$

$-0.029$

$-0.026$

$-0.03$

$-0.023$

$-0.028$

$[3.67]^{* *}$

$[2.72]^{* *}$

$[2.58]^{\star *}$

$[2.95]^{\star *}$

$[2.16]^{*}$

$[3.97]^{* *}$

GDP Growth

$-0.004$

[1.63]

Inflation

0.012

Observations

$[5.21]^{\text {** }}$

19735

Number of group (firm)

R-squared

3364

18613
3301

19735
3364
0.14

19735
3364
0.15

16181

19735

0.16

3364

3364

Robust t statistics in brackets

* significant at 5\%; ** significant at $1 \%$

Robustness results for specification (4)

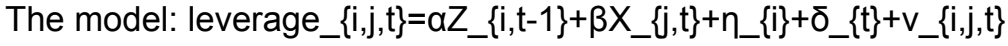

All regressions include firm fixed effects and year dummies (dummy for 2005 is excluded)

and have standard errors which are corrected for heteroskedasticity, and clustering at the

firm level (Rogers standard errors)

The firm characteristics are lagged one period to alleviate problems of endogeneity.

[1] controls for the macro economy

[2] only firms which have debt

[3] interaction of bank concentration with collateral

[4] interaction of bank concentration with size

[5] lagged bank concentration, bond market and stock market

[6] a dynamic specification where lagged market leverage is instrumented with lagged book leverage and the other variables in the regression (firm characteristics, HHI, Bond Market

and Stock Market Capitalization) 